\section{The Effect of Repeated Short-term Flooding on Mycorrhizal Survival in Snap Bean Roots}

Seema Sah

Department of Environmental Studies, The Honors College, Southeast Environmental Research Center, 11200 S.W. 8th Street, Florida International University, Miami, FL 33199

Stewart Reed ${ }^{1}$

U.S. Department of Agriculture, Agricultural Research Service, Subtropical Horticulture Research Station, 13601 Old Cutler Road, Miami, FL 33158

Krishnaswamy Jayachandran

Department of Environmental Studies, The Honors College, Southeast Environmental Research Center, 11200 S.W. 8th Street, Florida International University, Miami, FL 33199

\section{Christopher Dunn}

U.S. Department of Agriculture, Agricultural Research Service, Subtropical Horticulture Research Station, 13601 Old Cutler Road, Miami, FL 33158

Jack B. Fisher

Fairchild Tropical Botanic Garden, 11935 Old Cutler Road, Coral Gables, FL 33156-4233

Additional index words. arbuscular-mycorrhizal fungi, Glomus intraradices, Etrophospora columbiana, Gigaspora margarita, Gigaspora rosae, flood tolerance, percent colonization, spore germination, snap bean, Phaseolus vulgaris

Abstract. Since arbuscular-mycorrhizal (AM) fungi are aerobic, symbiosis was not considered significant under flooded conditions. However, AM colonization of wetland plants is now believed more common than previously thought. In the humid tropics, storms that result in standing water for 24 hours or less are common. Short-term floods, especially on sandy soils, may leach banded fertilizer, reducing uptake efficiency. Crops planted in flood prone areas are not normally enhanced with mycorrhizal mixes. However, mycorrhizal associations tolerant to wet conditions may improve nutrient uptake as plants recover from short-term flooding. Greenhouse studies were initiated to determine the effects of frequent short-term floods (two to four events) on mycorrhizal colonization and subsequent development in snap bean (Phaseolus vulgaris L.) plants. Flooding produced no obvious long-term physical effects on plant shoots. In the first study, flooding did not affect survival of colonies established before the first flood event. Percent root colonization in flooded vs. nonflooded treatments was not significantly different at either 31 or 50 days after planting (DAP). As root length increased there was a concomitant increase in colonization so that percent colonization remained approximately the same in both flooded and nonflooded treatments. In the second study, three weekly floods beginning 13 DAP (cotyledon leaf open only) did not inhibit initial mycorrhizal colonization. Mycorrhizal associations should form with snap bean under conditions subject to short-term flooding. Additional research is needed to determine the efficacy of different mycorrhizal mixes under short-term flooded conditions in the field.

Between 2002 and 2004, Florida harvested an average of 32900 acres of snap bean at a value of $\$ 143$ million (USDA-NASS, 2005). This ranked Florida as the largest producer of snap bean for fresh market in the United States.

About $60 \%$ of the acres planted to snap bean were in south Florida. The landscape in south Florida is flat, low-lying with a water table at or near the surface. The underlying bedrock is a porous limestone through which water moves

Received for publication 23 Dec. 2005. Accepted for publication 28 Feb. 2006. The authors would like to thank Susana Mendiola-Quadreny and Dale Stennett for their technical assistance. We also gratefully acknowledge financial support through Research Support Agreement number 58-6601-1-002 between FIU and USDA-ARS-SSA-SHRS. This paper is Southeast Environmental Research Center(SERC) contribution no. 320. Mention of a trademark, proprietary product, or vendor does not constitute a guarantee or warranty of the product by the U.S. Department of Agriculture and does not imply its approval to the exclusion of other products or vendors that also may be suitable.

${ }^{1}$ E-mailsreed@saa.ars.usda.gov. rapidly. A thin layer of soil, a few inches to seven feet thick, sits on top of the limestone bedrock. Most agricultural soils are between 1 and $2 \mathrm{ft}$ deep. The months between May and October are particularly vulnerable to heavy thunderstorms. This combination of thin soils, a high water table and heavy storms make the region subject to frequent, short-term flood events. Damage from flooding during the 2005 hurricane Katrina amounted to $\$ 400$ million, in south Florida alone (USDA-OCE, 2005).

Among the problems associated with flooding is the onset of anaerobic conditions, changes in soil redox, $\mathrm{pH}$, metal ion solubility and the build-up of harmful compounds such as ethylene (Drew, 1990; Grable, 1966). Plant responses to flooding include reduced stem growth, inhibition of leaf elongation, chlorosis, increased production of adventitious roots, and wilting (Aloni and Rosenshtein, 1982; Bradford and Dilley, 1978; Kuo and Chen, 1980).

Plant $\mathrm{CO}_{2}$ assimilation, nutrient uptake, and susceptibility to pathogens and predators are negatively affected by flooding (Bradford and Hsiao, 1982; Kozlowski, 1977; Nunez et al., 1999; Sundstrom and Pezeshki, 1988). Flooding affects nutrient availability in soil, as well as, a plants' ability to extract those nutrients.

Arbuscular-mycorrhizal (AM) fungi are beneficial fungi that live in the roots of most vascular plants. The plant supplies carbon for the fungal growth and in turn the AM enhances the uptake of relatively immobile nutrients such as phosphorus, sulfur, copper, zinc, and boron (Smith and Gianinazzi-Pearson, 1988). The fungi are able to grow out from the roots into areas of the soil where root hairs are unable to reach and transfer these nutrients back to the plant roots. Plants colonized by AM are less susceptible to infection by root pathogens and nematodes (Bagyaraj, 1984). Increased nutrient uptake, as well as, tolerance to drought, extreme $\mathrm{pH}$ in soil, and heavy metals are benefits derived from AM fungi. Suppression of root pathogens by AM fungi and improved revegetation in disturbed areas have been well documented. Limited research has been done on the flood tolerance of AM fungi that live in the roots of crop plants. Because they are aerobic, mycorrhizal plant root symbiosis was not considered significant under flooded conditions. However, AM colonization of wetland plants is now believed more common than previously thought (Aziz et al., 1995; Cooke and Lefor, 1998).

AM symbiosis influences soil moisture holding properties (Auge et al., 2001; Bearden, 2001), with potential consequences on water relations of plants growing in those soils. Adequate soil moisture generally favors AM development (Entry et al., 2002), however, when soil moisture becomes too high or low, it may suppress colonization. Flooding has been shown to inhibit AM fungal root colonization in purple nutsedge (Muthukumar et al., 1997). As soil wetness increases, mycorrhizal colonization of roots decreases (Miller, 2000; Rickeral et al., 1994).

Just as the distribution of plant species may 
change as soil moisture increases, different mycorrhizal fungi may predominate in wet than dry soil. Several studies in wetlands along a wet to dry transect show seasonal trends in mycorrhizal colonization of roots (Bohrer et al., 2004; Escudero and Mendoza, 2004; Miller, 2000). Where soil moisture exhibits a seasonal dry period, colonization may be determined by the plants ability to provide $\mathrm{C}$ for mycorrhizal development (Miller, 2000).

In wetland soil where flooding may persist for months at a time, plants are naturally selected for survival in wet conditions. Agricultural crops are rarely selected for flood tolerance. In addition, agricultural soils are often artificially drained and flooding tends to last no more than a few days. In the humid tropics severe thunderstorms may inundate fields for short durations several time throughout a growing season. Short-term floods, especially on sandy soils, may leach banded fertilizer, reducing plant fertilizer uptake efficiency. Crops planted in flood prone areas are not normally enhanced with mycorrhizal mixes applied as a seed coating. However, mycorrhizal associations tolerant to wet conditions may help improve nutrient uptake as plants recover from short-term flood events. Little is known about mycorrhizal colonization and growth in agricultural settings under periodic short-term flooding conditions. Greenhouse studies were initiated to determine the effects of frequent short-term floods on mycorrhizal colonization and subsequent development in snap bean (Phaseolus vulgaris L.) plants.

\section{Materials and Methods}

Two greenhouse experiments were conducted at the Subtropical Horticulture Research Station (Miami, Fla.) in 2004 and 2005 to determine the effect of flooding on initial AM colonization, and the survival of established hyphae.

Study 1. The first study was designed to determine if two to four periodic 8-h flood durations would affect the survival of established mycorrhizal colonies in snap bean roots. This experiment was conducted from 12 May to 2 July 2004 providing $14 \mathrm{~h}$ day length with a maximum photosynthetically active radiation (PAR) of $2100 \mu \mathrm{M} \cdot \mathrm{m}^{-2} \cdot \mathrm{s}^{-1}$. Soil temperature varied from 24 to $33{ }^{\circ} \mathrm{C}$. There were two mycorrhizal treatments; two flood termination dates plus uninoculated and unflooded controls, and five replications of each treatment (Table 1). Experimental treatments were arranged in a completely randomized design. To eliminate any differences in locations in the greenhouse pots were re-randomized weekly.

The mycorrhizal treatments were 1) no mycorrhizae, 2) Mycor mycorrhizal mix (Plant Health Care, Pittsburgh, Pa.) containing spores of Glomus intraradices and Etrophospora columbiana, and 3) Biorize mycorrhizal mix (Biorize Ltd. Dijon, France), containing Gigaspora margarita and Gigaspora rosae. Flooding began $20 \mathrm{~d}$ after planting (DAP) and was terminated either 31 or 50 DAP. At 20,31 , and 50 DAP, plants were at the twoleaf, three-leaf, and four- to five-leaf growth stages, respectively. Treatments were imposed by placing pots with the same mycorrhizal inoculum into a tank and filled with water to $1 \mathrm{~cm}$ above the soil surface. After eight hours, pots were taken from the tanks, allowed to drain and placed in new randomized positions on the benches. Water moving in response to gravity was completely drained in $15 \mathrm{~min}$. Flood treatments were defined as follows: 1) no flooding, 2) emersion in water to $1 \mathrm{~cm}$ above soil surface for $8 \mathrm{~h}$ once a week beginning 20 DAP and ending 31 DAP, and 3) emersion in water to $1 \mathrm{~cm}$ above soil surface for $8 \mathrm{~h}$ once a week beginning 20 DAP and ending 50 DAP. There were a total of two 8-h floods for the 31 DAP harvest and four floods for the 50 DAP harvest.

Plants were grown in 15 -L plastic pots with a mixture of 7 sand : 1.5 peat : 1.5 compost. The potting mix was steamed for $24 \mathrm{~h}$ allowed to cool and steamed again for an additional 24 h. A 4-g mycorrhizal inoculum was applied 5 $\mathrm{cm}$ below the surface of pots assigned to the Biorize and Mycor treatments. In each pot, four snap bean ('Mirada TG5863'; Syngenta Seed, Inc., Boise, Idaho) seeds were planted $2.5 \mathrm{~cm}$ above the inoculum. At emergence, pots were thinned to one plant per pot.

All pots were irrigated daily with $50 \mathrm{~mL}$ of Hoagland's solution (Hoagland and Arnon, 1950) plus enough water to replace $80 \%$ of pan evaporation. On average, the total amount of irrigation solution applied was $150 \mathrm{~mL}$ per day. The nitrogen content in each application $(0.01$ $\mathrm{g} \mathrm{N}$ ) was based on a total requirement for high yield from a snap bean plant averaged over a 65 $\mathrm{d}$ period from planting to harvest. Phosphorus content was adjusted to $0.003 \mathrm{~g} \cdot \mathrm{d}^{-1}$, equivalent to a moderate level of P fertility for a field crop. Other nutrients were supplied at a rate based on their ratio to $\mathrm{N}$ in full strength Hoagland's solution. Pan evaporation was calculated based on a formula derived from Dalton's law, $\mathrm{E}=\mathrm{C}$ $\left(e_{s}-e_{d}\right)$ for evaporation of free-water from the surface, where $e_{\mathrm{s}}$ is the saturated vapor pressure at ambient temperature, $e_{d}$ is the vapor pressure at ambient temperature, and $\mathrm{C}$ is a constant, from Meyer (1942) for pans and shallow ponds. Wind speed in the greenhouse was based on flow from cooling fans and measured at 0.28 $\mathrm{m} \cdot \mathrm{s}^{-1}$. Temperature, air pressure, and relative humidity were measured by a Greenhouse Weather Station, (Spectrum Technologies, Plainfield, Ill.).

Study 2. The second study compared the effects of three flooding events on initial mycorrhizal colonization of snap bean roots and survival of colonies established before flooding occurred. The experimental design (Table 1) featured four mycorrhizal levels, two flood regimes, and five replication of each treatment. Each flood initiation date was treated as a separate experiment. Treatments were arranged on benches in a completely randomized design. Eight treatments for each flood date included, three mycorrhizal types plus a nonmycorrhizal control subjected to either flooded or nonflooded conditions. The mycorrhizae used were Mycor and Biorize, described above, plus Fairchild mycorrhizal mix. The Fairchild inoculum (Fairchild Tropical Botanic Garden, Miami, Fla.) was cultured by Jack Fisher from various spores collected in a natural pine rockland forest. Fairchild inoculum was effective in AM colonization of a number of native southern Florida angiosperms, including legumes (Fisher and Jayachandran, 2005). Since little was known about the Fairchild mix and its inoculation strength was assumed to be weak, the inoculum was increased to $20 \mathrm{~g}$. Flooding was imposed as described above. This experiment began 11 Jan. 2005. Day length was $11 \mathrm{~h}$ with a maximum photosynthetically active radiation (PAR) of $2100 \mu \mathrm{M} \cdot \mathrm{m}^{-2} \cdot \mathrm{s}^{-1}$. Soil temperature varied from 26 to $30{ }^{\circ} \mathrm{C}$. The starting dates for the first flood were 13 DAP (first trifoliate leaf had not unfolded) or 23 DAP (three open leaves). This study had three, 8 -h floods for each harvest date. Plants were grown in 15-L plastic pots with a sand:perlite potting mixture at a 9:1 ratio replacing the sand-peat-compost mix which was not available. Potwere steamed, inoculated, planted, and thinned in the same manner as the first study except for the $20 \mathrm{-g}$ inoculum strength for Fairchild. Flooding treatments were stopped at $28 \mathrm{DAP}$ and 38 DAP for the flood treatments beginning 13 and 23 DAP, respectively. Plants were harvested at either 35 or 46 DAP.

Data collection. The same methods were used in both studies. Plant height, from the base of the stem to the uppermost node, was measured weekly and a growth rate determined as the weekly change in height. At harvest shoots were cut off at the soil surface and placed in labeled paper bags then oven dried at $45{ }^{\circ} \mathrm{C}$. Dry weights were recorded and subsamples collected for nutrient analysis. After shoots were harvested the remaining roots were carefully washed free of soil and blotted dry on a paper towel. Fresh weight was recorded, and then roots were stored at $4{ }^{\circ} \mathrm{C}$ until analysis. About $200 \mathrm{~g}$ of soil was collected from each

Table 1. Experimental design to determine the effect of short-term flooding on mycorrhizal colony survival (Study 1) and the effect of flooding on colony establishment (Study 2).

\begin{tabular}{|c|c|c|c|c|}
\hline Study & $\begin{array}{l}\text { Flood } \\
\text { treatment }\end{array}$ & $\begin{array}{l}\text { Mycorrhizae } \\
\text { inoculum }\end{array}$ & $\begin{array}{c}\text { Flood } \\
\text { initiation } \\
\text { date }\end{array}$ & $\begin{array}{c}\text { Harvest } \\
\text { date }\end{array}$ \\
\hline \multirow[t]{2}{*}{$\overline{1}$} & None & Biorize & $20 \mathrm{DAP}^{\mathrm{z}}$ & $31 \mathrm{DAP}$ \\
\hline & Weekly 8-h floods & $\begin{array}{l}\text { Mycor } \\
\text { Uninoculated }\end{array}$ & & 50 DAP \\
\hline \multirow[t]{2}{*}{2} & None & Biorize & 13 DAP & 35 DAP \\
\hline & Weekly 8-h floods & $\begin{array}{l}\text { Mycor } \\
\text { Fairchild } \\
\text { Uninoculated }\end{array}$ & 23 DAP & 45 DAP \\
\hline
\end{tabular}

${ }^{2} \mathrm{DAP}=$ days after planting. 
pot and stored at $4{ }^{\circ} \mathrm{C}$ for mycorrhizal spore counting.

Basal roots (originating from the lower hypocotyl or upper radical) and taproot were separated and counted. The tap and a subsample of the basal root were weighed and individually scanned on a commercial scanner. Root length was determined using Delta-T Scan software (Delta-T-Devices LTD., Cambridge, U.K.) and adjusted by weight to reflect the entire root assemblage.

After scanning, a portion of each root was weighed then dried at $45^{\circ} \mathrm{C}$ for nutrient and dry weight analysis. The remaining root mass was stored for mycorrhizal colonization determination. Root dry weights were adjusted for the total root assemblage based on the wet weight to dry weight ratio of the subsample and the wet weight of the whole root.

Secondary and tertiary roots were removed from main root system for mycorrhizal colonization analysis. These roots were placed in $70-\mathrm{mL}$ test tubes filled with enough $10 \%$ potassium hydroxide $(\mathrm{KOH})$ to cover the root mass and heated for $1 \mathrm{~h}$ at $90{ }^{\circ} \mathrm{C}$. The $\mathrm{KOH}$ was removed and roots were placed in $1 \%$ hydrochloric acid $(\mathrm{HCl})$ for $3 \mathrm{~min}$. The $\mathrm{HCl}$ was removed and roots were stained using a modification of the Phillips and Hayman (1970) procedure. Roots were covered with trypan blue and placed in an oven for $10 \mathrm{~min}$ at $110^{\circ} \mathrm{C}$. Trypan-blue stain was then drained off and roots covered with $50 \%$ lactic acid. The roots were rinsed with deionized water several times to lighten the stain. Stained roots were examined under a stereomicroscope for mycorrhizal colonization. The percent root infection was determined using the grid-line intersect method of Giovanetti and Mosse (1980). Fifty counts per dish were made for arbuscules, vesicles, hyphae, and total mycorrhizal colonization.

Statistical analysis was conducted using SAS software (SAS Inst. 1999). Analysis of variance (ANOVA) was used to determine treatment effects (flooding and mycorrhizal type) on plant height, shoot biomass, root length, root biomass and mycorrhizal colonization. Each sampling date was analyzed separately. Means separation was performed using the Fisher least significance difference test. Data were tested for normality by using Shapiro-Wilk and Kolmogorov-Smirnov test. Unless otherwise described, data satisfied the assumption of normal distribution.

\section{Results}

In the first study Fairchild mycorrhizal mix was not available and the mycorrhizal mixes used were Biorize and Mycor. Table 2 summarizes the effects of short-term flooding on root length, dry weight and percent colonization at two sampling dates. Data were combined across mycorrhizal types. At 31 DAP, the two periodic short-term flood events significantly reduced root length below that of nonflooded plants. Root dry weight also was less in the flooded treatments but the difference was not significant. By 50 DAP, the four weekly floods resulted in both root length and dry weight becoming significantly lower in the flooded than nonflooded plants. In this study the first flood event occurred 20 DAP when presumably the mycorrhizal inoculum had sufficient time to infect roots. Flooding after the initial infection did not significantly affect survival of existent colonies. Percent root colonization in flooded vs. nonflooded treatments was not significantly different at either sampling date. As root length increased from 31 to 50 DAP, there was a concomitant increase in colonization so that percent colonization, or mycorrhizal density, remained about the same in both flooded and nonflooded treatments. This is consistent with wetland studies by Miller and Sharitz (2000) who found flooding inhibits initial root colonization in semiaquatic grass but once mycorrhizae are established flooding has no effect.

The Mycor mycorrhizal mix had the high- est percent colonization at $31 \mathrm{DAP}$ in both the flood and nonflooded treatments (Table 3 ). Fifty days after planting the root length increased in nonflooded Mycor inoculated plants faster than new fungal growth as seen by the reduction in percent colonization from 31 DAP. Nonflooded Biorize inoculated plants had similar root lengths at the two sampling dates, however, fungal colonization increased with time. This may be due to a slow rate of colony establishment with Biorize. By 50 DAP, percent colonization was similar for both mycorrhizal types in the nonflooded treatments. With flooding, both Biorize and Mycor mycorrhizae maintained percent colonization with increased root length. Based on the higher percent colonization at 31 DAP in both flooded and nonflooded treatments Mycor appeared to more aggressively infect bean roots in the early stages of colonization than Biorize.

Table 2. Effect of short-term flooding on root length and dry weight (adjusted for total root assemblage), and percent colonization (determined on a subsample) of snap bean plants on two sampling dates, 31 and $50 \mathrm{~d}$ after planting (DAP). ${ }^{\mathrm{z}}$

\begin{tabular}{|c|c|c|c|c|c|c|}
\hline \multirow[b]{2}{*}{$\begin{array}{l}\text { Flood } \\
\text { treatment }\end{array}$} & \multicolumn{3}{|c|}{31 DAP } & \multicolumn{3}{|c|}{50 DAP } \\
\hline & $\begin{array}{l}\text { Root length } \\
\text { (m) }\end{array}$ & $\begin{array}{l}\text { Root dry } \\
\text { wt (g) }\end{array}$ & $\begin{array}{c}\text { Colonization } \\
(\%)\end{array}$ & $\begin{array}{l}\text { Root length } \\
\text { (m) }\end{array}$ & $\begin{array}{l}\text { Root dry } \\
\text { wt (g) }\end{array}$ & $\begin{array}{c}\text { Colonization } \\
(\%)\end{array}$ \\
\hline Flood & $4.965 \mathrm{~b}$ & $1.26 \mathrm{a}$ & $29 \mathrm{a}$ & $6.616 \mathrm{~b}$ & $1.11 \mathrm{~b}$ & $30 \mathrm{a}$ \\
\hline None & $8.093 \mathrm{a}$ & $1.73 \mathrm{a}$ & $31 \mathrm{a}$ & $10.775 \mathrm{a}$ & $2.21 \mathrm{a}$ & $35 \mathrm{a}$ \\
\hline
\end{tabular}

${ }^{\mathrm{z}}$ Means in the same column followed by the same letter are not significantly different at $P=0.05$ unless otherwise noted.

Table 3. Total root length and dry weight (adjusted for total root assemblage), and percent colonization (determined on a subsample) of snap bean plants with no mycorrhizae or inoculated with Biorize or Mycor mycorrhizae grown under either none flooded or flooded conditions (DAP = days after planting). ${ }^{z}$

\begin{tabular}{|c|c|c|c|c|c|c|c|}
\hline \multirow[b]{2}{*}{$\begin{array}{l}\text { Flood } \\
\text { treatment }\end{array}$} & \multirow[b]{2}{*}{$\begin{array}{l}\text { Mycorrhizal } \\
\text { type }\end{array}$} & \multicolumn{3}{|c|}{31 DAP } & \multicolumn{3}{|c|}{$50 \mathrm{DAP}$} \\
\hline & & $\begin{array}{l}\text { Root length } \\
\text { (m) }\end{array}$ & $\begin{array}{c}\text { Root dry } \\
\text { wt (g) }\end{array}$ & $\begin{array}{c}\text { Colonization } \\
(\%)\end{array}$ & $\begin{array}{l}\text { Root length } \\
\text { (m) }\end{array}$ & $\begin{array}{c}\text { Root dry } \\
\text { wt (g) }\end{array}$ & $\begin{array}{c}\text { Colonization } \\
(\%)\end{array}$ \\
\hline Flood & Biorize & 5.970 abc & $1.62 \mathrm{ab}$ & $30 \mathrm{~b}$ & $6.383 \mathrm{~cd}$ & $0.97 \mathrm{bc}$ & $30 \mathrm{~b}$ \\
\hline Flood & Mycor & $4.428 \mathrm{c}$ & $1.16 \mathrm{ab}$ & $58 \mathrm{a}$ & $7.287 \mathrm{bcd}$ & $0.90 \mathrm{c}$ & $52 \mathrm{a}$ \\
\hline Flood & None & $4.496 \mathrm{bc}$ & $1.02 \mathrm{~b}$ & $0 \mathrm{~d}$ & $4.127 \mathrm{~d}$ & $0.58 \mathrm{c}$ & $10 \mathrm{c}$ \\
\hline None & Biorize & $8.539 \mathrm{ab}$ & $1.25 \mathrm{ab}$ & $25 \mathrm{c}$ & $8.427 b c$ & $1.78 \mathrm{abc}$ & $48 \mathrm{a}$ \\
\hline None & Mycor & $9.546 \mathrm{a}$ & $2.42 \mathrm{a}$ & $65 \mathrm{a}$ & $13.126 \mathrm{a}$ & $2.69 \mathrm{a}$ & $48 \mathrm{a}$ \\
\hline None & None & $6.194 \mathrm{abc}$ & $1.53 \mathrm{ab}$ & $5 \mathrm{~d}$ & $10.772 \mathrm{ab}$ & $2.17 \mathrm{ab}$ & $10 \mathrm{~b}$ \\
\hline
\end{tabular}

${ }^{\mathrm{z}}$ Means in the same column followed by the same letter are not significantly different at $P=0.05$ level unless otherwise noted.

Table 4. Plant height, growth rate, leaf area and shoot biomass of snap bean plants with no mycorrhizae or with Biorize, Mycor, or Fairchild mycorrhizae inoculations grown under either non flooded or flooded conditions harvested 35 or $45 \mathrm{~d}$ after planting (DAP). ${ }^{\mathrm{z}}$

\begin{tabular}{cccccc}
\hline $\begin{array}{l}\text { Flood } \\
\text { treatment }\end{array}$ & $\begin{array}{c}\text { Mycorrhizal } \\
\text { type }\end{array}$ & $\begin{array}{c}\text { Plant ht } \\
(\mathrm{cm})\end{array}$ & $\begin{array}{c}\text { Growth rate } \\
\left(\mathrm{cm} \cdot w^{-1}\right)\end{array}$ & $\begin{array}{c}\text { Shoot dry } \\
\text { wt }(\mathrm{g})\end{array}$ & $\begin{array}{c}\text { Leaf area } \\
\left(\mathrm{cm}^{2}\right)\end{array}$ \\
\hline 35 DAP & Biorize & $24.8 \mathrm{abc}$ & $6.7 \mathrm{a}$ & $5.4 \mathrm{~b}$ & $754 \mathrm{ab}$ \\
Flood & Fairchild & $22.6 \mathrm{bc}$ & $5.9 \mathrm{bc}$ & $3.8 \mathrm{~d}$ & $754 \mathrm{ab}$ \\
Flood & Mycor & $27.5 \mathrm{a}$ & $6.8 \mathrm{a}$ & $6.4 \mathrm{a}$ & $920 \mathrm{a}$ \\
Flood & None & $21.3 \mathrm{c}$ & $5.4 \mathrm{~cd}$ & $5.1 \mathrm{bc}$ & $846 \mathrm{ab}$ \\
Flood & Biorize & $24.1 \mathrm{abc}$ & $5.8 \mathrm{bcd}$ & $5.5 \mathrm{~b}$ & $841 \mathrm{ab}$ \\
None & Fairchild & $26.1 \mathrm{ab}$ & $6.3 \mathrm{ab}$ & $4.8 \mathrm{bc}$ & $712 \mathrm{ab}$ \\
None & Mycor & $21.2 \mathrm{c}$ & $5.0 \mathrm{~d}$ & $4.4 \mathrm{~cd}$ & $632 \mathrm{~b}$ \\
None & None & $24.2 \mathrm{abc}$ & $6.3 \mathrm{ab}$ & $5.2 \mathrm{bc}$ & $834 \mathrm{ab}$ \\
None & & & & $18.9 \mathrm{ab}$ & $1733 \mathrm{a}$ \\
45 DAP & Biorize & $39.7 \mathrm{a}$ & $5.9 \mathrm{~b}$ & $14.5 \mathrm{cde}$ & $1616 \mathrm{ab}$ \\
Flood & Fairchild & $42.3 \mathrm{a}$ & $6.6 \mathrm{ab}$ & $18.0 \mathrm{abc}$ & $1805 \mathrm{a}$ \\
Flood & Mycor & $43.3 \mathrm{a}$ & $7.2 \mathrm{ab}$ & $11.8 \mathrm{e}$ & $1481 \mathrm{~b}$ \\
Flood & None & $42.7 \mathrm{a}$ & $7.1 \mathrm{ab}$ & $15.8 \mathrm{bcd}$ & $1720 \mathrm{ab}$ \\
Flood & Biorize & $45.1 \mathrm{a}$ & $7.5 \mathrm{a}$ & $20.7 \mathrm{a}$ & $1633 \mathrm{ab}$ \\
None & Fairchild & $45.9 \mathrm{a}$ & $7.4 \mathrm{a}$ & $12.7 \mathrm{de}$ & $1681 \mathrm{ab}$ \\
None & Mycor & $43.9 \mathrm{a}$ & $7.7 \mathrm{a}$ & $12.8 \mathrm{de}$ & $1642 \mathrm{ab}$ \\
None & None & $42.3 \mathrm{a}$ & $7.4 \mathrm{a}$ & \\
None & None & &
\end{tabular}

${ }^{\mathrm{z}}$ Means in the same column followed by the same letter are not significantly different at $P=0.05$ level unless otherwise noted. 
Table 5. Root length and dry weight (adjusted for total root assemblage), and percent mycorrhizal colonization (determined on a subsample) by either Biorize, Mycor, or Fairchild mycorrhizal mixture for plants subjected to three 8-h floods or normal soil moisture conditions (DAP = days after planting). ${ }^{z}$

\begin{tabular}{|c|c|c|c|c|c|c|c|}
\hline \multirow{2}{*}{$\begin{array}{l}\text { Flood } \\
\text { treatment }\end{array}$} & \multirow{2}{*}{$\begin{array}{c}\text { Mycorrhizal } \\
\text { type }\end{array}$} & \multicolumn{2}{|c|}{ Root length (m) } & \multicolumn{2}{|c|}{ Root dry wt (g) } & \multicolumn{2}{|c|}{ Colonization (\%) } \\
\hline & & $35 \mathrm{DAP}$ & 45 DAP & $35 \mathrm{DAP}$ & $45 \mathrm{DAP}$ & 35 DAP & $45 \mathrm{DAP}$ \\
\hline Flood & Biorize & $31.7 \mathrm{c}$ & 84.9 bc & $0.64 \mathrm{~b}$ & $1.46 \mathrm{~d}$ & $27.4 \mathrm{c}$ & $51.2 \mathrm{a}$ \\
\hline Flood & Fairchild & $26.5 \mathrm{c}$ & $66.6 \mathrm{c}$ & $0.65 \mathrm{~b}$ & $3.00 \mathrm{bc}$ & $35.6 \mathrm{~b}$ & $39.6 \mathrm{~b}$ \\
\hline Flood & Mycor & $70.0 \mathrm{a}$ & $73.3 \mathrm{bc}$ & $0.99 \mathrm{ab}$ & $2.86 \mathrm{bcd}$ & $48.8 \mathrm{a}$ & $44.8 \mathrm{~b}$ \\
\hline Flood & none & $43.4 \mathrm{bc}$ & $68.0 \mathrm{c}$ & $0.68 \mathrm{~b}$ & $1.89 \mathrm{~cd}$ & $6.0 \mathrm{de}$ & $10.0 \mathrm{c}$ \\
\hline None & Biorize & $34.3 \mathrm{bc}$ & $55.5 \mathrm{c}$ & $0.96 \mathrm{ab}$ & $3.37 \mathrm{ab}$ & $12.8 \mathrm{~d}$ & $44.2 \mathrm{~b}$ \\
\hline None & Fairchild & $55.4 \mathrm{~b}$ & $64.2 \mathrm{c}$ & $1.29 \mathrm{a}$ & $2.00 \mathrm{bcd}$ & $10.4 \mathrm{~d}$ & $59.6 \mathrm{a}$ \\
\hline None & Mycor & $39.8 \mathrm{bc}$ & $124.1 \mathrm{a}$ & $0.93 \mathrm{~b}$ & $4.49 \mathrm{a}$ & $8.0 \mathrm{de}$ & $47.6 \mathrm{a}$ \\
\hline None & none & $37.2 \mathrm{bc}$ & $107.5 \mathrm{ab}$ & $0.95 \mathrm{ab}$ & $2.50 \mathrm{bcd}$ & $2.8 \mathrm{e}$ & $10.4 \mathrm{c}$ \\
\hline
\end{tabular}

${ }^{\mathrm{z}}$ Means in the same column followed by the same letter are not significantly different at $P=0.05$ level.

In the second planting, the initiation offlood treatments were timed to determine if waterlogging would inhibit initial mycorrhizal infection and/or subsequent fungal growth. Table 4 shows selected shoot physical characteristics by flood treatment and mycorrhizal type. At 35 DAP, flooded Mycor mycorrhizae treated plants had the greatest height, biomass and leaf area. Nonflooded Mycor had the lowest height and leaf area while flooded Fairchild had the lowest biomass. By 45 DAP there were few significant differences in plant height and leaf area. Flooded and nonflooded uninoculated plants accounted for two out of the three lowest recorded biomasses.

In general, flooded plants tended to yield higher biomass than nonflooded regardless whether flooding occurred before or after fungal inoculants infected plants. Whereas flooding reduced soil $\mathrm{O}_{2}$ content and leaf photosynthetic $\mathrm{CO}_{2}$ exchange up to $24 \mathrm{~h}$ after plants were allowed to drain (data not shown), overall, there were no obvious long-term physical effects on plant shoots from flooding.

Table 5 describes root length, dry weight and percent fungal colonization for the different flood and mycorrhizal treatments. Flooded Mycor treatment had the greatest root length and flooded Fairchild the smallest at 35 DAP. Nonflooded Mycor and Biorize had the greatest and smallest root lengths, respectively, at 45 DAP. Combining data across treatments, Mycor inoculated plants tended to have longer roots than the other treatments. In general, root lengths did not differ between flood and nonflood treatments; however, nonflooded roots exhibited greater lateral branching than flooded roots.

Flooding had the greatest effect on root dry weights. Combined across flood treatments, data show significantly greater dry weight for the nonflooded vs. flooded plants. At 35 DAP, the difference was $1.03 \mathrm{~g}$ for nonflooded and $0.74 \mathrm{~g}$ for flooded plants. At 45 DAP, the difference was 3.09 vs. $2.28 \mathrm{~g}$ for the nonflooded and flooded plants, respectively. Both the flooded and nonflooded treatments received the same daily nutrient content. However, we cannot discount the potential for some nutrient loss from flooded pots as they drained. There were no significant differences in shoot dry weights between flooded and nonflooded treatments. The root:shoot ratio was 0.15 and 0.21 for the flooded and nonflooded treatments, respectively. Flooded treatments apparently allocated relatively less energy into root verses shoot production than the nonflooded. We attribute this to the enhanced water status of the flooded treatment, which lasted for $24 \mathrm{~h}$ after each flooding event.

\section{Discussion}

Based on experience it was determined that the potting soils used in these studies did not contain enough $\mathrm{P}$ to support snap bean plants beyond the first leaf stage. Therefore, the fertility level, especially that of $\mathrm{P}$, was selected to provide sufficient nutrients to allow plants to make continuous development to flowering. Since fertilizer was added daily, at no time did the total soil $\mathrm{P}$ content (equivalent to about $17 \mathrm{lb} / \mathrm{ac}$ ) approach levels that would be considered inhibitory to mycorrhizae in the field $(>40 \mathrm{lb} / \mathrm{ac})$. Phosphorus levels applied in this study did not excessively inhibit formation of mycorrhizae/root associations. Snap bean, managed for maximum production, normally flowers at roughly $36 \mathrm{~d}$. In this study flowering began at about 45 DAP during both years. The delay in flowering was likely caused by the low $\mathrm{P}$ application rate.

Except for root dry weight, flooding had little long-term effect on plant characteristics. However, flooding tended to improve initial fungal colonization regardless of the mycorrhizal type (Table 5). In the second study a sandier potting mix was used with a much lower water holding capability. Plants were watered at 9:00 AM, the hottest time of day was 4:00 PM. Irrigation was not applied to the point where water drained freely through pots but only in quantities sufficient to replace water loss through evapotranspiration. The low water holding capacity of the potting mix may have resulted in less than optimal moisture conditions by the end of each day. Weekly 8 -h floods beginning 13 DAP (35 DAP treatment) likely improved pot moisture conditions while not allowing time for excessive depletion in $\mathrm{O}_{2}$ by the relatively small root mass. Saturating the potting soil may have favored spore germination in flooded pots over the nonflooded. This worked to the benefit of initial mycorrhizal colonization of the developing root system. By 45 DAP, however, nonflooded and flooded roots had similar colonization percentages. Short-term, periodic flooding initiated after mycorrhizae had become established in root tissue (45 DAP treatment) had little effect on survival of the colonies. At 45 DAP, Biorize had the greatest percent colonization in flood treated plants and Fairchild the greatest in nonflooded plants.

Where mycorrhizae were allowed to first colonize roots, subsequent short-term flooding had little effect on survival of fungal colonies. In this greenhouse study, three weekly floods beginning 13 DAP ( $7 \mathrm{~d}$ after plant emergence) did not inhibit initial mycorrhizal colonization.

Graham and Eissenstat (1998) report that in a production scheme with high $\mathrm{P}$ fertility mycorrhizae act as a carbon drain on citrus. Under these circumstances mycorrhizal associations may be parasitic to the host plant. In our study there were few differences in dry weight between inoculated and uninoculated plants. Harvest occurred when plants were at the three to four leaf stage (31 or 35 DAP) or at the four to five leaf stage ( 45 or 50 DAP). In general, plants were harvested before flowering when the demand for carbohydrates would be great. There was a slight, nonsignificant tend for greater root dry weight production in inoculated plants. However, given the short duration of this study and that plants had not yet reached maximum growth at harvested, the problem of excessive fungal carbon demand was not apparent.

Additional research is needed to determine the efficacy of different mycorrhizal mixes under short-term flooded conditions in the field. The effects of different soil types and longer flood durations on colonization also need to be clarified. Nevertheless, mycorrhizal associations should form with snap bean under field conditions subject to short-term flooding.

\section{Literature Cited}

Aloni, B. and G. Rosenshtein. 1982. Effect offlooding on tomato cultivars: The relationship between proline accumulation and other morphological and physiological changes. Physiol. Plant. 56:513-517.

Auge, R.M., A J.W. Stodola, J.E. Tims, and A.M. Saxton. 2001. Moisture retention properties of a mycorrhizal soil. Plant Soil 230:87-97.

Aziz, T., D.M. Sylvia, and R.F. Doren. 1995. Activity and species composition of arbuscular mycorrhizal fungi following soil removal. Ecol. Appl. 5:776-784.

Bagyaraj, D.J. 1984. Biological interactions with VA mycorrhizal fungi, p.131-153. In: C.L. Powell and D.J. Bagyaraj (eds.). VA mycorrhizae. CRC Press, Boca Raton, Fla.

Bearden, B.N. 2001. Influences of arbuscular mycorrhizal fungi on soil structure and soil water characteristics of vertisols. Plant Soil 229:245-258

Bohrer, K.E., C.F. Friese, and J.P. Amon. 2004. Seasonal dynamics of arbuscular mycorrhizal fungi in differing wetland habitats. Mycorrhiza 14:329-337.

Bradford, K.J. and D.R. Dilley. 1978. Effects of root anaerobiosis on ethylene production, epinasty, and growth of tomato (Lycopersicon esculentum) plants. Plant Physiol. 61:506-509.

Bradford, K.J. and T.C. Hsiao. 1982. Stomatal behavior and water relations of waterlogged tomato (Lycopersicon esculentum) plants. Plant Physiol. 70:1508-513.

Cooke, J.C. and M.W. Lefor. 1998. The mycorrhizal status of selected plant species from Connecticut wetlands and transition zones. Restor. Ecol. 6:214-222. 
Drew, M.C. 1990. Sensing soil oxygen. Plant Cell Envi. 13:681-693.

Entry, J.A, P.T. Rygiewicz, L.S. Watrud, and P.K. Donnelly. 2002. Influences of adverse soil conditions on the formation and function of arbuscular mycorrhizas. Adv. Environ. Res 7:123-138.

Escudero, V. and R. Mendoza. 2004. Seasonal variation of arbuscular mycorrhizal fungi in temperate grasslands along a wide hydrologic gradient. Mycorrhiza 15:291-299.

Fisher, J.B. and K. Jayachandran. 2005. Presence of arbuscular mycorrhizal fungi in South Florida native plants. Mycorrhiza 15:580-588.

Giovanetti, M. and B. Mosse. 1980. An evaluation of technique for measuring vesicular-arbuscular mycorrhizal infection in roots. New Phytol. 84:489-500.

Grable, A.H. 1966. Soil aeration and plant growth. Adv. Agron. 18:57-106.

Graham, J.H. and D.M. Eissenstat. 1998. Field evidence for the carbon cost of citrus mycorrhizas. New Phytol. 140:103-110.

Hoagland, D.R. and D.I. Arnon. 1950. The water culture method of growing plants without soil. Calif. Agr. Expt. Sta.
Kozlowski, I.T. 1977. Responses of woody plants to flooding and salinity. Tree physiology monograph no. 1. Heron Publ., Victoria.

Kuo, C.G. and B.W. Chen. 1980. Physiological responses of tomato cultivars to flooding. J. Amer. Soc. Hort. Sci. 105:751-755.

Meyer, A.F. 1942. Evaporation from lakes ans reservoirs. Minn. Resour. Comm., St. Paul.

Miller, S.P. 2000. Arbuscular mycorrhizal colonization of semi-aquatic grasses along a wide hydrologic gradient. New Phytol. 145:145-155.

Miller, S.P. and R.R. Sharitz. 2000. Manipulation of flooding and arbuscular mycorrhizal formation influences growth and nutrition of two semiaquatic species. Funct. Ecol. 14:738-748.

Muthukumar T., K. Udaiyan, A. Karthikeyan, and S. Manian. 1997. Influence of native endomycorrhiza, soil flooding and nurse plant on mycorrhizal status and growth of purple nutsedge (Cyperus rotundus L.). Agr. Ecosystem Environ. 61:51-58.

Núñez, R.E., B. Schaeffer, J.B. Fisher, A.M. Colls, and J.H. Crane. 1999. Influence of flooding on net $\mathrm{CO}_{2}$ assimilation, growth, and stem anatomy of Annona species. Ann. Bot. 84:771-780.
Phillips, J.M. and D.S. Hayman 1970. Improved procedures for clearing roots and staining parasitic and vesicular-arbuscular mycorrhizal fungi for rapid assessment of infection. Br. Mycol. Soc. 55:158-161.

Rickeral, D.H., F.O. Sancho, and S. Ananth. 1994. Vesicular arbuscular endomycorrhizal colonization of wetland plants. J. Environ. Qual. 23:913-916.

SAS Institute. 1999. SAS for windows. SAS Inst. Cary, N.C.

Smith, S.E. and V. Gianinazzi-Pearson. 1988. Physiological interactions between symbionts in vesicular-arbuscular mycorrhizal plants. Annu. Rev. Plant Physiol. Plant Mol. Biol. 39:221-244.

Sundstrom, F.J. and S.R. Pezeshki. 1988. Reduction of Capsicum annuum L. growth and seed quality by soil flooding. HortScience. 23(3):574-576.

USDA-NASS Agricultural Statistics 2005, Vegetables and melons. www.nass.usda.gov.

USDA-OCE, 2005. A preliminary assessment of the effects of Katrina and drought on U.S. agriculture. 2005. www.usda.gov/oce/katrinadamage ___2. pdf. 